\title{
Characterization and optimization of xylanase and endoglucanase production by Trichoderma viride HG 623 using response surface methodology (RSM)
}

\author{
Xiaomei Huang ${ }^{1 \#}$, Jiangli Ge ${ }^{2 \#}$, Jinxia Fan ${ }^{1}$, Xiuling Chen ${ }^{1}$, Xiuhong $\mathrm{Xu}^{1 *}$, Jingfu $\mathrm{Li}^{1 *}$, \\ Yubo Zhang ${ }^{2}$ and Dongyue Zhou ${ }^{2}$ \\ ${ }^{1}$ Northeast Agricultural University, Harbin 150030, China. \\ ${ }^{2}$ Heilongjiang Province Mudanjiang Forestry Scientific Research Institute, Mudanjiang 157009, China.
}

Accepted 26 August, 2013

\begin{abstract}
Xylanase and endoglucanase production from Trichoderma viride HG 623 and their properties were investigated in this research. By using response surface methodology, the optimal concentrations for xylanase and endoglucanase production were carbon (rice straw: corn straw=6:1), $26.91 \mathrm{~g} / \mathrm{L} ; \mathrm{NH}_{4} \mathrm{Cl}$, $3.77 \mathrm{~g} / \mathrm{L} ; \mathrm{KH}_{2} \mathrm{PO}_{4}, 5.31 \mathrm{~g} / \mathrm{L}$ and carbon (rice straw:corn straw=6:1), $26.99 \mathrm{~g} / \mathrm{L} ; \mathrm{NH}_{4} \mathrm{Cl}, 3.80 \mathrm{~g} / \mathrm{L}$, and $\mathrm{KH}_{2} \mathrm{PO}_{4}, 5.23 \mathrm{~g} / \mathrm{L}$, respectively. Under these optimal conditions, the xylanase and endoglucanase activity from $T$. viride HG 623 reached 135.51 and $40.89 \mathrm{IU} / \mathrm{g}$, respectively. Verification of the optimization showed that xylanase and endoglucanase activity were 139.57 and $41.46 \mathrm{IU} / \mathrm{g}$, respectively. The optimal $\mathrm{pH}$ of xylanase and endoglucanase activity from T. viride HG 623 was 5.0 and the optimal temperature were 60 and $55^{\circ} \mathrm{C}$, respectively. The activity of xylanase and endoglucanase were stable when incubated from 35 to $55^{\circ} \mathrm{C}$ for $1 \mathrm{~h}$. The xylanase and endoglucanase activity of $T$. viride HG 623 were stable from $\mathrm{pH} 3.0$ to 7.5 at $50^{\circ} \mathrm{C}$. Xylanase activity showed the highest level $(150.36 \mathrm{IU} / \mathrm{g})$ when activated by $75 \mathrm{mM}$ of $\mathrm{Co}^{2+}$, and endoglucanase activity reached the highest level $(36.99 \mathrm{IU} / \mathrm{g})$ when activated by $75 \mathrm{mM}$ of $\mathrm{Mg}^{2+}$. The wheat bran was the optimal natural substrate for enzyme production of $T$. viride HG 623. The results of this study would instruct the cellulase and hemicellulase production on industrial scale.
\end{abstract}

Key words: Trichoderma viride HG 623, xylanase, endoglucanase, response surface methodology, characterization.

\section{INTRODUCTION}

It is well known that energy consumption has increased progressively as the result of growing world population and industrialization. Owing to the realization of diminishing natural oil and gas resources, interests in the bioconversion of abundant and renewable cellulosic biomass into fuel ethanol as an alternative to petroleum is rising around the world (Cardona and Sánchez, 2007). Huge quantities of agro-industrial biomass are produced worldwide annually, that is including about 900 million tons of rice straw (RS) which more than $90 \%$ are produced in Asia (Jahromi et al., 2011). The RS mainly consists of cellulose, hemicellulose and lignin. Cellulose and hemicelluloses could been degraded into hextose and pentose which are able to be fermented into ethanol by Saccharomyces cerevisiae and Pichia stipits, respectively (Agbogbo and Coward-Kelly, 2008). However, the degradation of cellulose and hemicellulose is the limiting step during the conversion of biomass into bioenergy. 
Xylanases (1,4- $\beta$-D-xylan xylanohydrolase; EC 3.2.1.8) are the main constituents of the xylanolytic enzyme system, which hydrolyze xylan into Xylo-oligosaccharide mostly (Geetha and Gunasekaran, 2010; Zhang et al., 2011; Shin et al., 2009). Endoglucanases are parts of the cellulase complex involved in cellulose degradation. They attack cellulose fibres at random and cleave them at more amorphous regions which, in turn, create sites for other enzymes like exoglucanases and $\beta$-glucosidases (Yoon et al., 2008). The synergistic action of endoglucanase (EG), cellobiohydrolase (CBH) and $\beta$-glucosidase with the help of hemicellulases (mainly xylanases) results in the complete degradation of cellulosic materials (Quiroz et al., 2011; García et al., 2007).

The traditional 'one-factor at a time' technique used for optimizing a multivariable system is not only time-consuming but also often easily misses the alternative effects between components. Conventional methods for optimal culture conditions based on the classical method of 'onevariable-at-a-time' bioprocess design in which, one independent variable is studied while fixing all others at a specific level, may be effective in some situations, but may fail to consider the combined effects of all involved factors and lead to misleading results and inaccurate conclusions (Silva and Roberto, 2001). Recently, many statistical experimental design methods have been employed in bioprocess optimization. Among them, response surface methodology (RSM) is the one suitable for identifying the effect of individual variables and for seeking the optimum conditions for a multivariable system efficiently (Li et al., 2007a; Maria et al., 2009).

The optimization of culture medium and culture conditions for improvement of the production of CMCase and xylanases have been reported by many scholars (Evangelos et al., 2003; Sonia et al., 2005; Irfan et al., 2012; Romdhane et al., 2010). In this study, response surface methodology (RSM) was used to determine the effects of several variables and to optimize enzyme production conditions. The mathematical models were established and showed the relation of the enzyme activity to independent variables. By this way, the maximum enzyme activity was ensured through the prediction of the optimum values of the independent variables. Further-more, the characterization of xylanase and endoglucanase from the $T$. viride $\mathrm{HG} 623$ were researched.

\section{MATERIALS AND METHODS}

\section{Microorganism and preparation of spore suspension}

T. viride HG 623 was selected from a screening from $T$. viride CICC13038 (obtained from China Center of Industrial Culture Collection) mutated by physical and chemical methods. Briefly, spore suspension of $T$. viride CICC13038 $(5 \mathrm{~mL})$ was treated with $2 \%$ diethyl sulfate for 20 min and then illuminated 2 min with an 30$\mathrm{w}$ ultraviolet lamp. The mutant producing the highest enzyme activity was selected and named $T$. viride $\mathrm{HG} 623$. It was cultured on potato dextrose agar (PDA) for 10 generations, and then maintained on PDA at $4^{\circ} \mathrm{C}$.
Spore suspension of $T$. viride HG 623 was washed from the PDA plate with sterile water then inoculated in $100 \mathrm{~mL}$ of potato dextrose broth in a 500-mL Erlenmeyer flask, and the spores were grown at $28^{\circ} \mathrm{C}$ on PDA at $250 \mathrm{rpm}$ for $48 \mathrm{~h}$.

\section{Raw material}

Rice straw and corn straw were dried overnight at $70^{\circ} \mathrm{C}$ and cut into approximate $1 \mathrm{~cm}$ size, then sifted by 50 meshes sieve. The fractions passing through sieve were used as the substrate for submerged cultivation.

\section{Medium and culture conditions}

The medium used for enzyme production was composed of $(\mathrm{g} / \mathrm{L})$ : Tween 80, 1.5; $\mathrm{MgSO}_{4} \cdot 7 \mathrm{H}_{2} \mathrm{O}, 0.3 ; \mathrm{CaCl}_{2} .2 \mathrm{H}_{2} \mathrm{O}, 0.3 ; \mathrm{FeSO}_{4} \cdot 7 \mathrm{H}_{2} \mathrm{O}$, $0.005 ; \mathrm{ZnSO}_{4} \cdot 7 \mathrm{H}_{2} \mathrm{O}, 0.0014 ; \mathrm{MnSO}_{4} \cdot \mathrm{H}_{2} \mathrm{O}, 0.0016$ and $\mathrm{CoCl}_{2} \cdot 7 \mathrm{H}_{2} \mathrm{O}$, 0.002 (Van Wyk and Mohulatsi, 2003). The concentrations of Carbon, $\mathrm{NH}_{4} \mathrm{Cl}$ and $\mathrm{KH}_{2} \mathrm{PO}_{4}$ were adjusted according to the experimental design. The $\mathrm{pH}$ was adjusted to 5.0-6.0.The spore culture $(10.0 \%)$ was inoculated in $20 \mathrm{~mL}$ of individual test media in $50 \mathrm{~mL}$ shake-flask. Then, the flasks were incubated on a shaker at $28^{\circ} \mathrm{C}$, $250 \mathrm{rpm}$ for 5 days. Crude enzyme preparation was obtained from the enzyme-containing broth by centrifugation at $5,000 \times g$ for 10 $\min$.

\section{Enzyme assay}

The xylanase activity was determined by measuring the release of reducing sugars from oat spelt xylan $(1 \% \mathrm{w} / \mathrm{v})$ using the dinitrosalicylic acid method (Miller, 1959). The reaction mixture, containing $1 \mathrm{ml}$ of a solution of $1 \%$ oat spelt xylan in a citrate buffer $50 \mathrm{mM}, \mathrm{pH} 5.0$ plus $1 \mathrm{ml}$ of the diluted crude enzyme, was incubated for $30 \mathrm{~min}$ at $50^{\circ} \mathrm{C}$. One unit of xylanase was defined as the amount of enzyme required to release $1 \mathrm{mmol}$ of xylose from xylan per minute under the assay conditions.

The CMCase activity was measured by using Meinke's procedure (Meinke et al., 1995) with some modifications. The reaction mixture, consisting of $1 \mathrm{ml} 1 \% \mathrm{CMC}-\mathrm{Na}$ as the substrate and $0.5 \mathrm{ml}$ of cultured supernatant after centrifugation, was incubited at $50^{\circ} \mathrm{C}$ for $30 \mathrm{~min}$, supplemented with $0.5 \mathrm{ml}$ of 3,5-dinitrosalicylic acid and boiled for $10 \mathrm{~min}$. After cooling, the reduced sugars released in response to CMCase activity were measured at $540 \mathrm{~nm}$. One unit of CMCase activity was defined as the amount of enzyme required for releasing total reduced sugar equivalent to 1 $\mu \mathrm{mol}$ glucose per minute.

\section{Plackett-Burman experimental design}

The Plackett-Burman experimental design (Plackett and Burman, 1946) based on the first-order model:

$Y=\beta_{0}+\Sigma \beta_{i} X_{i}$

Used to screen the important variables that influence enzyme production. Total number of trials to be carried out according to the Plackett-Burman was $\mathrm{k}+1$, where $\mathrm{k}$ is number of variables (medium components). Each variable is represented at two levels (high and low) that are denoted by $(+1)$ and $(-1)$, respectively (Table 1$)$.

\section{Central composite design}

According to the central composite design (CCD) (Box and Wilson, 
Table 1. Range of variables at different levels for the fractional factorial design.

\begin{tabular}{lcc}
\hline \multirow{2}{*}{ Independent variables $\mathbf{X i}(\mathbf{g} / \mathbf{L})$} & \multicolumn{3}{c}{ Level } \\
\cline { 2 - 3 } & $\mathbf{- 1}$ & $\mathbf{1}$ \\
\hline $\mathrm{X}_{1}{ }^{*}$ Carbon & 10 & 40 \\
$\mathrm{X}_{2} \mathrm{NH}_{4} \mathrm{Cl}$ & 1 & 5 \\
$\mathrm{X}_{3} \mathrm{KH}_{2} \mathrm{PO}_{4}$ & 1 & 5 \\
$\mathrm{X}_{4} \mathrm{FeSO}_{4} \cdot 7 \mathrm{H}_{2} \mathrm{O}$ & 0.003 & 0.007 \\
$\mathrm{X}_{5} \mathrm{MnSO}_{4} \cdot \mathrm{H}_{2} \mathrm{O}$ & 0.001 & 0.002 \\
$\mathrm{X}_{6} \mathrm{ZnSO}_{4} \cdot 7 \mathrm{H}_{2} \mathrm{O}$ & 0.001 & 0.002 \\
$\mathrm{X}_{7} \mathrm{MgSO}_{4} \cdot 7 \mathrm{H}_{2} \mathrm{O}$ & 0.1 & 0.5 \\
$\mathrm{X}_{8} \mathrm{CaCl}_{2}$ & 0.1 & 0.5 \\
$\mathrm{X}_{9} \mathrm{CoCl}_{2} \cdot 7 \mathrm{H}_{2} \mathrm{O}$ & 0.001 & 0.003 \\
$\mathrm{X}_{10} \mathrm{Tween}_{80}$ & 1 & 3 \\
\hline
\end{tabular}

${ }^{*}$ Carbon contained rice and corn stalk (6:1).

1951), a five-level, three-factor factorial central composite design and nine replicates at the center points leading to 23 runs was employed for the optimization of the enzymatic production. The variables were coded according to Equation:

$\mathrm{X}_{\mathrm{i}}=\left(\mathrm{X}_{\mathrm{i}}-\mathrm{X}_{0}\right) / \Delta \mathrm{X}_{\mathrm{i}}$

Where, $X_{i}$ is the coded value, $X_{i}$ is the real value, $X_{0}$ is the real value at the center point, and $\Delta X_{i}$ is the step change value.

A second-order polynomial model for predicting the optimal point was expressed as Equation:

$\mathrm{Y}=\mathrm{A}_{0}+\Sigma A i X i+\Sigma A i i X i^{2}+\Sigma A i j \mathrm{X}_{\mathrm{i}} \mathrm{X}_{\mathrm{j}}$

Where, $Y$ is the predicted response, $A_{0}$ is the interception coefficient, $A i$ is the linear effect, $A i i$ is the squared effect, and $A i j$ the interaction effect. The accuracy and general ability of the above polynomial model could be evaluated by the coefficient of determination $R^{2}$.

\section{The characterization assays of enzymes}

The stability of $\mathrm{pH}$ was measured by incubating the crude enzyme in different $\mathrm{pH}$ using buffer solutions $50 \mathrm{mM}$ sodium citrate ( $\mathrm{pH} 3.0$ 6.0), sodium phosphate $(\mathrm{pH} 6.5$ - 8.0), and Tris- $\mathrm{HCl}(\mathrm{pH} 8.5-9.0)$ for $48 \mathrm{~h}$ at $4^{\circ} \mathrm{C}$, and then the residual activity was measured under standard conditions $(\mathrm{pH}=5.0)$. The optimum $\mathrm{pH}$ was explored at $50^{\circ} \mathrm{C}$ between $\mathrm{pH} 3$ and 9 at intervals of $0.5 \mathrm{pH}$ units.

Thermal stability was assayed by incubating the crude enzyme at different temperature (ranging $30-90^{\circ} \mathrm{C}$ at intervals of $5^{\circ} \mathrm{C}$ ) in 50 $\mathrm{mM}$ citrate buffer, $\mathrm{pH} 5.2$, for $1 \mathrm{~h}$, and then the residual activity was measured by incubation at $50^{\circ} \mathrm{C}$ for $30 \mathrm{~min}$. The optimum temperature was studied at $\mathrm{pH} 5.6$ between 30 and $90^{\circ} \mathrm{C}$ at $5^{\circ} \mathrm{C}$ intervals for 30 min, using CMC-Na and oat spelt xylan as substrate

To investigate the effect of ions on enzymatic activity, the enzyme activity was assayed in the reaction buffer supplemented with $75 \mathrm{mM}$ of metal ion. Several different buffer solutions were prepared; each contained a different metal salt $\left(\mathrm{MgSO}_{4}, \mathrm{AgNO}_{3}, \mathrm{ZnSO}_{4}\right.$, $\left.\mathrm{CuSO}_{4}, \mathrm{BaCl}_{2}, \mathrm{FeCl}_{3}, \mathrm{FeSO}_{4}, \mathrm{CoCl}_{2}, \mathrm{MnSO}_{4}, \mathrm{Al}_{2}\left(\mathrm{SO}_{4}\right)_{3}, \mathrm{CaCl}_{2}\right)$. All of the above experiments were completed in triplicate, and average values were calculated based on results from three independent experiments.

To study the effect of various substrates on enzyme activity, 1.5 $\mathrm{ml} 1 \%$ substrates was added into reaction system, containing of 0.5 $\mathrm{ml}$ of crude enzyme preparation, and incubated for $30 \mathrm{~min}$ at $50^{\circ} \mathrm{C}$. Carboxymethyl cellulose sodium (CMC-Na), filter, cotton, rice stalk, corn stalk, wheat bran, wheat straw, sawdust, soybean straw, coconut shell and CCM were used as different substrates.

\section{RESULTS}

\section{Screening of Significant Nutrient Components for Xylanase and Endoglucanase Production by T. viride HG 623}

Ten factors were chosen to optimize the condition for enzyme production of $T$. viride HG 623 (Table 1). Table 2 shows the Plackett-Burman design for 12 trials, which were two levels of concentrations for ten different nutrient components and corresponding enzyme activity. It was found that the variables $\mathrm{X}_{1}$ (Carbon), $\mathrm{X}_{2}\left(\mathrm{NH}_{4} \mathrm{Cl}\right)$, and $\mathrm{X}_{3}$ $\left(\mathrm{KH}_{2} \mathrm{PO}_{4}\right)$ had significant influence on xylanase and endoglucanase production $(\mathrm{P}<0.05) \quad($ Table 3$)$ in ten variables.

\section{Regression models of response}

Thevariables $\mathrm{X}_{1}$ (Carbon), $\mathrm{X}_{2}\left(\mathrm{NH}_{4} \mathrm{Cl}\right)$ and $\mathrm{X}_{3}\left(\mathrm{KH}_{2} \mathrm{PO}_{4}\right)$ were confirmed as important factors through the factorial analysis of Plackett-Burman experiment. The coded values of variables are shown in Table 4. The optimal concentrations of these three variables needed to be further measured by CCD design. The experimental responses for the 23 runs are presented in Table 5. The multiple regression equations (Equation 2) for xylanase and endoglucanase production were performed on the experimental data.

$Y_{1}=126.195+9.3169 X_{1}+8.3884 X_{2}+8.7119 X_{3}+0.5727$ $X_{1} X_{2}+0.6790 \quad X_{2} X_{3}-0.2320 \quad X_{1} X_{3}-6.9511 X_{1}^{2}-5.9909 X_{2}^{2}-$ $6.9047 \mathrm{X}_{3}^{2}$

$\mathrm{Y}_{2}=36.3283+4.4854 \mathrm{X}_{1}+4.8224 \mathrm{X}_{2}+3.4610 \mathrm{X}_{3}$ $+0.3781 X_{1} X_{2}+0.7968 \quad X_{2} X_{3}+0.6994 \quad X_{1} X_{3}-3.7323 X_{1}^{2}$ $3.4738 X_{2}^{2}-3.7455 X_{3}^{2}$

Where, $Y$ was the predicted response $\left[x y l a n a s e\left(Y_{1}\right)\right.$ and 
Table 2. Plackett-Burman design matrix for ten variables with the experimental values of xylanase and endoglucanse activity by $T$. viride HG 623.

\begin{tabular}{ccccccccccccc}
\hline Run & $\mathbf{X}_{\mathbf{1}}$ & $\mathbf{X}_{\mathbf{2}}$ & $\mathbf{X}_{\mathbf{3}}$ & $\mathbf{X}_{\mathbf{4}}$ & $\mathbf{X}_{\mathbf{5}}$ & $\mathbf{X}_{\mathbf{6}}$ & $\mathbf{X}_{\mathbf{7}}$ & $\mathbf{X}_{\mathbf{8}}$ & $\mathbf{X}_{\mathbf{9}}$ & $\mathbf{X}_{\mathbf{1 0}}$ & $\begin{array}{c}\text { Xylanase activity } \\
(\mathbf{I U} / \mathbf{g})\end{array}$ & $\begin{array}{c}\text { Endoglucanase } \\
\text { activity (IU/g) }\end{array}$ \\
\hline 1 & 1 & -1 & 1 & -1 & -1 & -1 & 1 & 1 & 1 & -1 & 74.78 & 25.22 \\
2 & 1 & 1 & -1 & 1 & -1 & -1 & -1 & 1 & 1 & 1 & 80.36 & 24.96 \\
3 & -1 & 1 & 1 & -1 & 1 & -1 & -1 & -1 & 1 & 1 & 74.08 & 23.01 \\
4 & 1 & -1 & 1 & 1 & -1 & 1 & -1 & -1 & -1 & 1 & 76.40 & 23.73 \\
5 & 1 & 1 & -1 & 1 & 1 & -1 & 1 & -1 & -1 & -1 & 81.19 & 25.21 \\
6 & 1 & 1 & 1 & -1 & 1 & 1 & -1 & 1 & -1 & -1 & 98.57 & 30.61 \\
7 & -1 & 1 & 1 & 1 & -1 & 1 & 1 & -1 & 1 & -1 & 70.12 & 21.78 \\
8 & -1 & -1 & 1 & 1 & 1 & -1 & 1 & 1 & -1 & 1 & 64.58 & 20.06 \\
9 & -1 & -1 & -1 & 1 & 1 & 1 & -1 & 1 & 1 & -1 & 33.11 & 2.28 \\
10 & 1 & -1 & -1 & -1 & 1 & 1 & 1 & -1 & 1 & 1 & 71.75 & 22.28 \\
11 & -1 & 1 & -1 & -1 & -1 & 1 & 1 & 1 & -1 & 1 & 71.72 & 22.27 \\
12 & -1 & -1 & -1 & -1 & -1 & -1 & -1 & -1 & -1 & -1 & 31.45 & 9.78 \\
\hline
\end{tabular}

Table 3. Effect estimates for xylanase and endoglucanase production from the results of the Placket-Burman design.

\begin{tabular}{llcccccccc}
\hline \multirow{2}{*}{ Factor } & \multirow{2}{*}{ MC } & \multicolumn{4}{c}{ Xylanase } & \multicolumn{3}{c}{ Endoglucanase } \\
\cline { 3 - 9 } & & Es. & SE & T ratio & P value & Es. & SE & T ratio & P value \\
\hline $\mathrm{X}_{1}$ & Carbon\# & 22.999 & 0.925 & 24.85 & $0.0256^{*}$ & 7.476 & 0.0459 & 162.80 & $0.0039^{*}$ \\
$\mathrm{X}_{2}$ & $\mathrm{NH}_{4} \mathrm{Cl}$ & 20.659 & 0.925 & 22.32 & $0.0285^{*}$ & 6.082 & 0.0459 & 132.46 & $0.0048^{*}$ \\
$\mathrm{X}_{3}$ & $\mathrm{KH}_{2} \mathrm{PO}_{4}$ & 14.823 & 0.925 & 16.02 & $0.0397^{*}$ & 4.937 & 0.0459 & 107.51 & $0.0059^{*}$ \\
$\mathrm{X}_{4}$ & $\mathrm{FeSO}_{4}$ & -2.766 & 0.925 & -2.99 & 0.2055 & -1.193 & 0.0459 & -25.97 & 0.0245 \\
$\mathrm{X}_{5}$ & $\mathrm{MnSO}_{4}$ & 3.074 & 0.925 & 3.32 & 0.1861 & 0.621 & 0.0459 & 13.53 & 0.0470 \\
$\mathrm{X}_{6}$ & $\mathrm{ZnSO}_{4}$ & 2.540 & 0.925 & 2.74 & 0.2224 & 0.456 & 0.0459 & 9.92 & 0.0639 \\
$\mathrm{X}_{7}$ & $\mathrm{MgSO}_{4}$ & 6.695 & 0.925 & 7.23 & 0.0875 & 2.412 & 0.0459 & 52.53 & 0.0121 \\
$\mathrm{X}_{8}$ & $\mathrm{CaCl}_{2}$ & 3.022 & 0.925 & 3.27 & 0.1892 & 1.272 & 0.0459 & 27.70 & 0.0230 \\
$\mathrm{X}_{9}$ & $\mathrm{CoCl}_{2}$ & -3.285 & 0.925 & -3.55 & 0.1748 & -0.687 & 0.0459 & -14.96 & 0.0425 \\
$\mathrm{X}_{10}$ & $\mathrm{Tween}_{10}$ & 8.276 & 0.925 & 8.94 & 0.0709 & 2.237 & 0.0459 & 48.72 & 0.0131 \\
\hline
\end{tabular}

MC, Medium components; Es., estimate; SE, standard error. *Significant at $5 \%$ level $(P<0.05)$; \#Carbon contained rice and corn stalk $(6: 1)$

Table 4. Coded values of variables used in central composite design.

\begin{tabular}{lccccc}
\hline \multirow{2}{*}{ Independent variable $\mathbf{X i}(\mathbf{g} / \mathbf{L})$} & $\mathbf{- 1 . 6 8}$ & $\mathbf{- 1}$ & $\mathbf{0}$ & $\mathbf{1}$ & $\mathbf{1 . 6 8}$ \\
\cline { 2 - 6 } & 3.18 & 10 & 20 & 30 & 36.82 \\
\hline $\mathrm{X}_{1} \#$ Carbon & 1.32 & 2 & 3 & 4 & 4.68 \\
$\mathrm{X}_{2} \mathrm{NH}_{4} \mathrm{Cl}$ & 0.64 & 2 & 4 & 6 & 7.36 \\
$\mathrm{X}_{3} \mathrm{KH}_{2} \mathrm{PO}_{4}$ &
\end{tabular}

\#Carbon contained rice straw and corn stalk (6:1).

endoglucanase $\left(Y_{2}\right)$ production]; $X_{1}, X_{2}, X_{3}$ were coded values of carbon concentration, $\mathrm{NH}_{4} \mathrm{Cl}$ concentration and $\mathrm{KH}_{2} \mathrm{PO}_{4}$ concentration, respectively. The statistical significance of Equation 2 was done by the analysis of variance (ANOVA) in Table 6 . The coefficients of determination $\left(R^{2}\right)$ were 0.9496 and 0.9607 for xylanase and endoglucanase production, illustrating that the sample variation of more than $94.96 \%$ and $96.07 \%$ were explained by the fitted models.
The significant coefficients of the full second-order polynomial model of xylanase and endoglucanase production were shown through the Student $t$-distribution and the corresponding $P$-value (Table 7). The $P$-values of less than 0.05 indicated the more significant correlation of coefficients. Table 7 suggests that the independent variables $\mathrm{X}_{1}$ (Carbon concentration), $\mathrm{X}_{2}\left(\mathrm{NH}_{4} \mathrm{Cl}\right.$ concentration), $\mathrm{X}_{3}\left(\mathrm{KH}_{2} \mathrm{PO}_{4}\right.$ concentration) and the quadric term of these three variables had a significant effect on xylanase pro- 
Table 5. Central composite experiment design matrix with experimental values of xylanase and endoglucanase production by $T$. viride HG 623 .

\begin{tabular}{|c|c|c|c|c|c|}
\hline \multirow{2}{*}{ Trial number } & \multicolumn{3}{|c|}{ Variable } & \multicolumn{2}{|c|}{ Response } \\
\hline & $\mathrm{X}_{1}$ (Carbon) & $\mathrm{X}_{2}\left(\mathrm{NH}_{4} \mathrm{Cl}\right)$ & $\mathrm{X}_{3}\left(\mathrm{KH}_{2} \mathrm{PO}_{4}\right)$ & Xylanase activity (IU/g) & CMCase activity (IU/g) \\
\hline 1 & -1 & -1 & -1 & 89.36 & 16.32 \\
\hline 2 & -1 & -1 & 1 & 99.50 & 19.26 \\
\hline 3 & -1 & 1 & -1 & 95.67 & 21.99 \\
\hline 4 & -1 & 1 & 1 & 114.65 & 27.13 \\
\hline 5 & 1 & -1 & -1 & 100.47 & 22.03 \\
\hline 6 & 1 & -1 & 1 & 115.81 & 26.78 \\
\hline 7 & 1 & 1 & -1 & 115.20 & 28.22 \\
\hline 8 & 1 & 1 & 1 & 127.13 & 37.15 \\
\hline 9 & -1.68179 & 0 & 0 & 85.14 & 17.06 \\
\hline 10 & 1.68179 & 0 & 0 & 125.46 & 35.95 \\
\hline 11 & 0 & -1.68179 & 0 & 88.08 & 16.60 \\
\hline 12 & 0 & 1.68179 & 0 & 127.94 & 37.87 \\
\hline 13 & 0 & 0 & -1.68179 & 86.82 & 18.88 \\
\hline 14 & 0 & 0 & 1.68179 & 124.04 & 34.05 \\
\hline 15 & 0 & 0 & 0 & 126.55 & 36.75 \\
\hline 16 & 0 & 0 & 0 & 126.33 & 36.85 \\
\hline 17 & 0 & 0 & 0 & 125.08 & 35.24 \\
\hline 18 & 0 & 0 & 0 & 125.38 & 35.23 \\
\hline 19 & 0 & 0 & 0 & 126.94 & 36.40 \\
\hline 20 & 0 & 0 & 0 & 127.00 & 36.92 \\
\hline 21 & 0 & 0 & 0 & 125.07 & 35.28 \\
\hline 22 & 0 & 0 & 0 & 127.71 & 37.79 \\
\hline 23 & 0 & 0 & 0 & 126.13 & 36.24 \\
\hline
\end{tabular}

Table 6. Analysis of variance for the response of xylanase and endoglucanase production.

\begin{tabular}{lccccccccc}
\hline \multirow{2}{*}{ Source } & \multirow{2}{*}{ DF } & \multicolumn{9}{c}{ Xylanase $^{\mathbf{a}}$} & \multicolumn{5}{c}{ Endoglucanase $^{\mathbf{b}}$} \\
\cline { 2 - 10 } & & SS & MS & $\boldsymbol{F}$-value & $\boldsymbol{P}>\boldsymbol{F}$ & SS & MS & $\boldsymbol{F}$-value & $\boldsymbol{P}>\boldsymbol{F}$ \\
\hline Linear & 3 & 3182.95 & - & 148.25 & $<0.0001^{*}$ & 755.94 & - & 172.40 & $<0.0001^{*}$ \\
Quadratic & 3 & 2095.55 & - & 97.6 & $<0.0001^{*}$ & 635.99 & - & 145.05 & $<0.0001^{*}$ \\
Cross product & 3 & 6.74 & - & 0.31 & 2.3070 & 10.14 & - & 2.31 & 1.2815 \\
Total model & 9 & 5256.85 & 584.09 & 27.20 & $<0.0001^{*}$ & 1393.40 & 154.82 & 35.31 & $<0.0001^{*}$ \\
Total error & 13 & 279.12 & 21.47 & - & - & 57.00 & 4.38 & - & - \\
\hline
\end{tabular}

DF, Degree of freedom; SS: Sum of squares; MS, Mean square. ${ }^{a}$ coefficient of variation $(C V)=4.05$; coefficient determination $\left(R^{2}\right)=$ 0.9496; correlation coefficient $(R)=0.9745$; ${ }^{b}$ coefficient of variation $(\mathrm{CV})=7.0206$; coefficient determination $\left(R^{2}\right)=0.9607$; correlation coefficient $(R)=0.9802$. * Significant at $5 \%$ level $(\mathrm{P}<0.05)$.

duction and endoglucanase production. Interactions between the three variables had no significance $(P>0.05)$.

\section{Localization of optimum condition}

The optimal values of the independent variables for enzyme production could be observed from the 3D response surface plots and the corresponding contour plots (Figures 1 to 3 ). Figure $1 \mathrm{~A}$ and $\mathrm{B}$ show the effect of Carbon and $\mathrm{NH}_{4} \mathrm{Cl}$ on the endoglucanase and xylanase production by $T$. viride $\mathrm{HG}$ 623, while $\mathrm{KH}_{2} \mathrm{PO}_{4}$ was fixed at its middle level $(4 \mathrm{~g} / \mathrm{L})$. The endoglucanase and xylanase production reached a maximum point when concentrations of carbon and $\mathrm{NH}_{4} \mathrm{Cl}$ were used between 24-30 and 3.6-4.2 g/L, respectively. Figure $2 \mathrm{~A}$ and $\mathrm{B}$ present the effects of carbon and $\mathrm{KH}_{2} \mathrm{PO}_{4}$ on the endoglucanase and xylanase production, while $\mathrm{NH}_{4} \mathrm{Cl}$ concentration was fixed at its middle level $(3 \mathrm{~g} / \mathrm{L})$. The maximum endoglucanase and xylanase activity predicted from the model when concentrations of Carbon and $\mathrm{KH}_{2} \mathrm{PO}_{4}$ were used between 24-30 and 5.0-6.0 g/L, respectively. Figure $3 \mathrm{~A}$ and $\mathrm{B}$ show the effects of $\mathrm{NH}_{4} \mathrm{Cl}$ and $\mathrm{KH}_{2} \mathrm{PO}_{4}$ on the 
Table 7. The least-square fit and parameters (significant of regression coefficient) for the response of xylanase and endoglucanase production.

\begin{tabular}{|c|c|c|c|c|c|c|c|c|c|}
\hline \multirow{2}{*}{$\begin{array}{l}\text { Model } \\
\text { term }\end{array}$} & \multirow{2}{*}{ DF } & \multicolumn{4}{|c|}{ Xylanase } & \multicolumn{4}{|c|}{ Endoglucanase } \\
\hline & & Estimate & SE & $t$-value & $P>|t|$ & Estimate & SE & $t$-value & $P>|t|$ \\
\hline $\begin{array}{l}\text { Interce } \\
\text { pt }\end{array}$ & 1 & 126.195 & 1.544 & 81.76 & $<0.0001$ & 36.328 & 0.698 & 52.08 & $<0.0001^{*}$ \\
\hline$X_{1}$ & 1 & 9.317 & 1.254 & 7.43 & $<0.0001^{*}$ & 4.485 & 0.567 & 7.92 & $<0.0001^{*}$ \\
\hline$X_{2}$ & 1 & 8.388 & 1.254 & 6.69 & $<0.0001^{*}$ & 4.822 & 0.567 & 8.51 & $<0.0001^{\star}$ \\
\hline$X_{3}$ & 1 & 8.712 & 1.254 & 6.95 & $<0.0001^{*}$ & 3.461 & 0.567 & 6.11 & $<0.0001^{*}$ \\
\hline $\mathrm{X}_{1} \mathrm{X}_{2}$ & 1 & 0.573 & 1.638 & 0.35 & 0.7322 & 0.378 & 0.740 & 0.51 & 0.6181 \\
\hline $\mathrm{X}_{2} \mathrm{X}_{3}$ & 1 & 0.679 & 1.638 & 0.41 & 0.6853 & 0.797 & 0.740 & 1.08 & 0.3014 \\
\hline$x_{1} x_{3}$ & 1 & -0.232 & 1.638 & -0.14 & 0.8895 & 0.699 & 0.740 & 0.94 & 0.3620 \\
\hline$X_{1}^{2}$ & 1 & -6.951 & 1.162 & -5.98 & $<0.0001^{*}$ & -3.732 & 0.525 & -7.10 & $<0.0001^{\star}$ \\
\hline$X_{2}^{2}$ & 1 & -5.991 & 1.162 & -5.15 & $0.0002^{*}$ & -3.474 & 0.525 & -6.61 & $<0.0001^{*}$ \\
\hline$x_{3}{ }^{2}$ & 1 & -6.905 & 1.162 & -5.94 & $<0.0001^{*}$ & -3.746 & 0.525 & -7.13 & $<0.0001^{*}$ \\
\hline
\end{tabular}

DF, Degree of freedom; SE, standard error. *Significant at $5 \%$ level $(P<0.05)$.
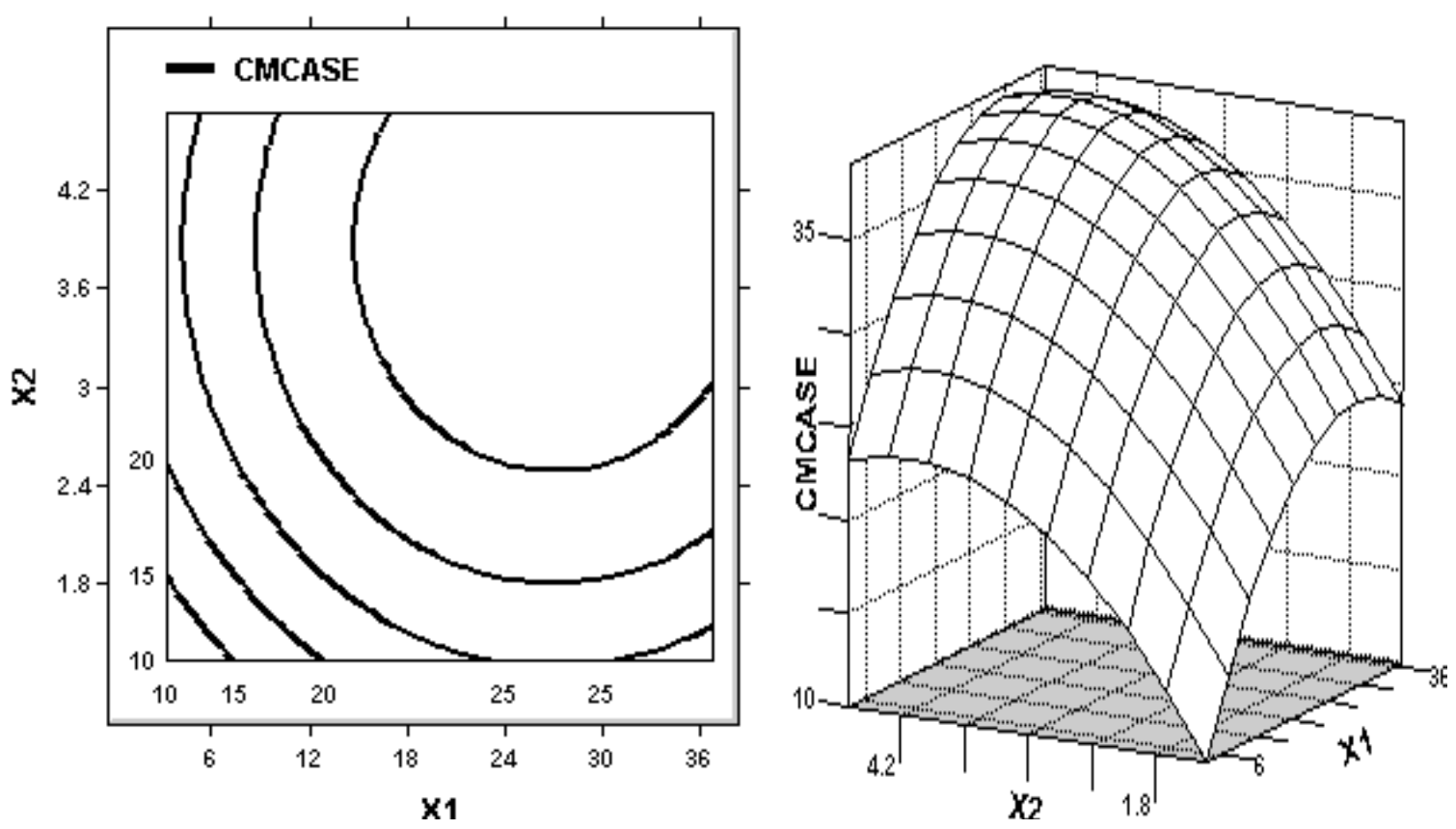

Figure 1A. Response surface plot and contour plot of the combined effects of Carbon and $\mathrm{NH}_{4} \mathrm{Cl}$ on the $\mathrm{CMCase}$ production by $T$. viride HG 623 with constant cultivation time $(120 \mathrm{~h})$.

endoglucanase and xylanase production, while Carbon concentration was fixed at its middle level $(20 \mathrm{~g} / \mathrm{L})$. The optimum pairs of $\mathrm{NH}_{4} \mathrm{Cl}$ and $\mathrm{KH}_{2} \mathrm{PO}_{4}$ concentration for maximum endoglucanase and xylanase activity were between 3.6-4.2 and 5.0-6.0 g/L, respectively. Based on these results, the optimal concentrations of Carbon, $\mathrm{NH}_{4} \mathrm{Cl}$ and $\mathrm{KH}_{2} \mathrm{PO}_{4}$ for xylanase production were calculated as $26.91,3.77$ and $5.31 \mathrm{~g} / \mathrm{L}$, respectively. When these concentrations of carbon, $\mathrm{NH}_{4} \mathrm{Cl}$ and $\mathrm{KH}_{2} \mathrm{PO}_{4}$ were used, the maximum xylanase activity predicted from the model was $135.51 \mathrm{lU} / \mathrm{g}$. The optimum concentrations for endoglucanase production were $40.89 \mathrm{IU} / \mathrm{g}$ when concentrations of Carbon, $\mathrm{NH}_{4} \mathrm{Cl}$ and $\mathrm{KH}_{2} \mathrm{PO}_{4}$ were 26.99, 3.80 and $5.23 \mathrm{~g} / \mathrm{L}$, respectively.

The evaluated experiments were carried out under optimal condition. The xylanase and endoglucanase activity were $139.57 \mathrm{IU} / \mathrm{g}$ and $41.46 \mathrm{IU} / \mathrm{g}$ when the optimal concentrations of carbon, $\mathrm{NH}_{4} \mathrm{Cl}$ and $\mathrm{KH}_{2} \mathrm{PO}_{4}$ were used. The mean values of xylanase and endoglucanase were $3.0 \%$ and $1.4 \%$ more than the predicted value, respectively. 

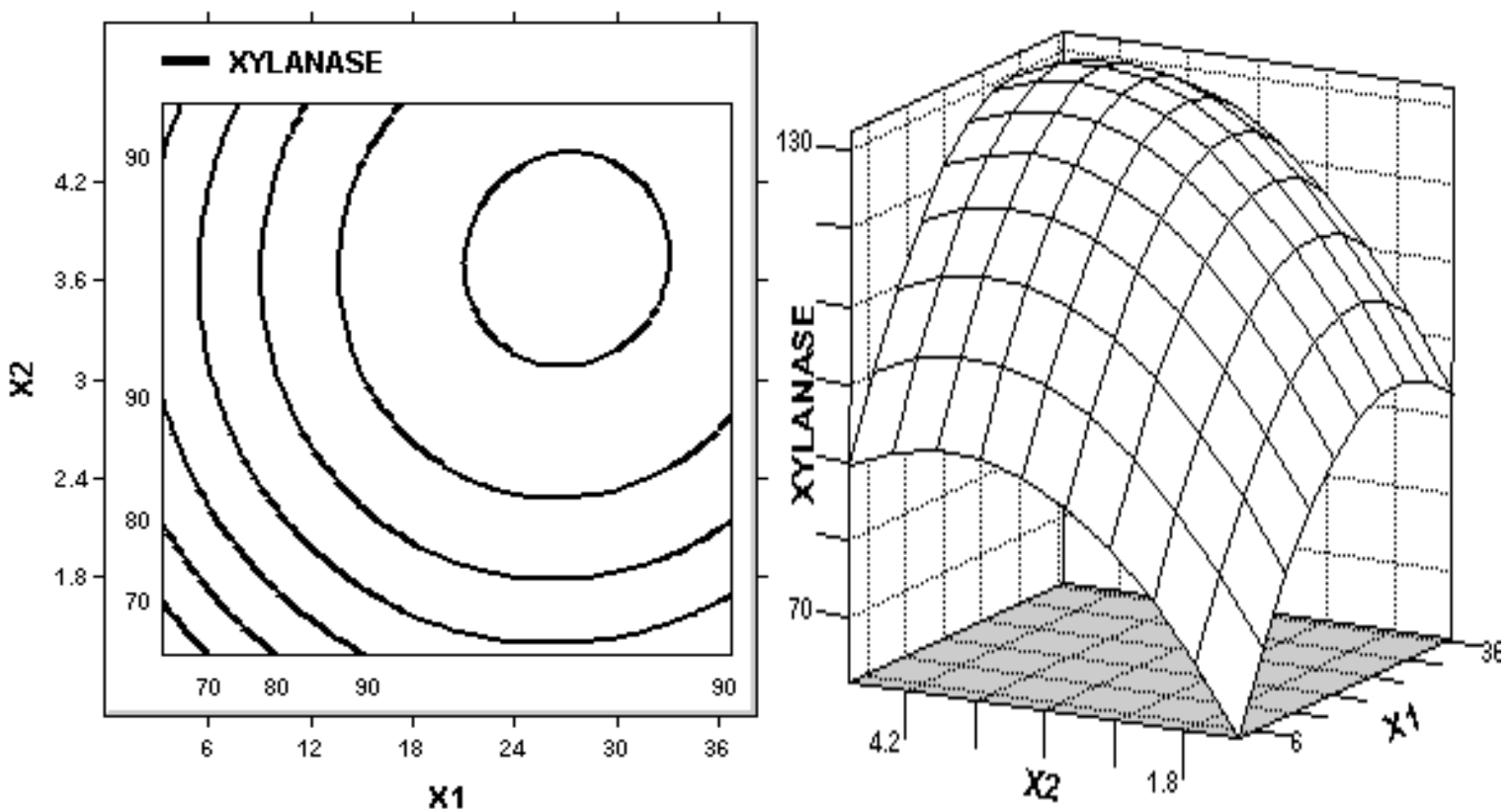

Figure 1B. Response surface plot and contour plot of the combined effects of Carbon and $\mathrm{NH}_{4} \mathrm{Cl}$ on the $x y l a n a s e$ production by $T$. viride HG 623 with constant cultivation time (120 h).
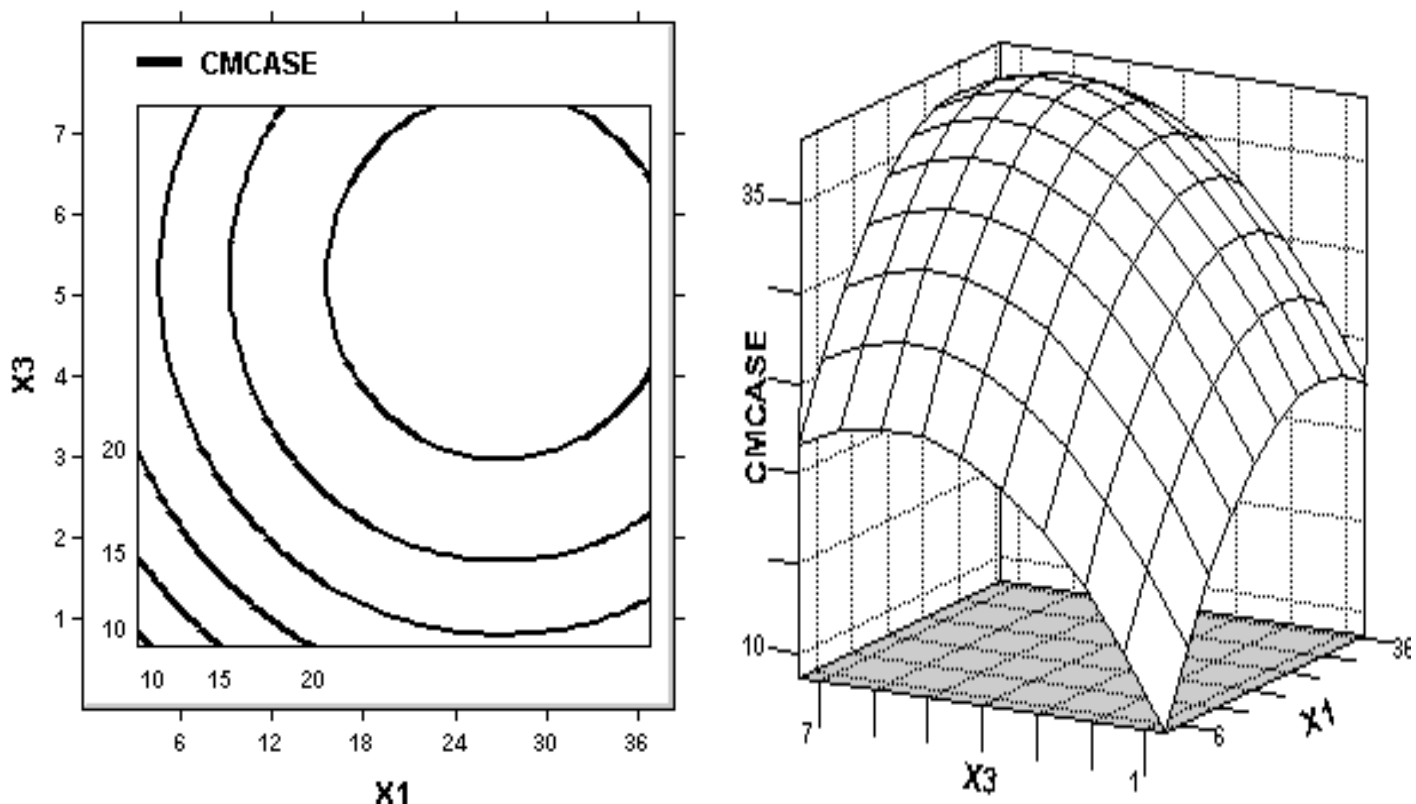

Figure 2A. Response surface plot and contour plot of the combined effects of Carbon and $\mathrm{KH}_{2} \mathrm{PO}_{4}$ on the CMCase production by T. viride HG 623 with constant cultivation time (120 h).

Properties of xylanase and endoglucanase from $T$. viride HG 623

The xylanase activity rose slowly from 30 to $60^{\circ} \mathrm{C}$, reached its summit at $60^{\circ} \mathrm{C}$, and reduced beyond $60^{\circ} \mathrm{C}$. The endoglucanase activity increased slowly from 30 to $55^{\circ} \mathrm{C}$, reached its peaked at $55^{\circ} \mathrm{C}$, and decreased beyond $55^{\circ} \mathrm{C}$. Conclu- sively, the optimal temperature for the xylanase and endoglucanase activity was $60^{\circ} \mathrm{C}$ and $55^{\circ} \mathrm{C}$, respectively (Figure 4A). The xylanase and endoglucanase activities were stable after incubation for $1 \mathrm{~h}$ from 35 to $55^{\circ} \mathrm{C}$ and decreased rapidly when tem-perature was beyond $60^{\circ} \mathrm{C}$ (Figure 4B). The activities of xylanase and endoglucanase were the highest at pH 5.0 (Figure $4 \mathrm{C}$ ). The xylanase 

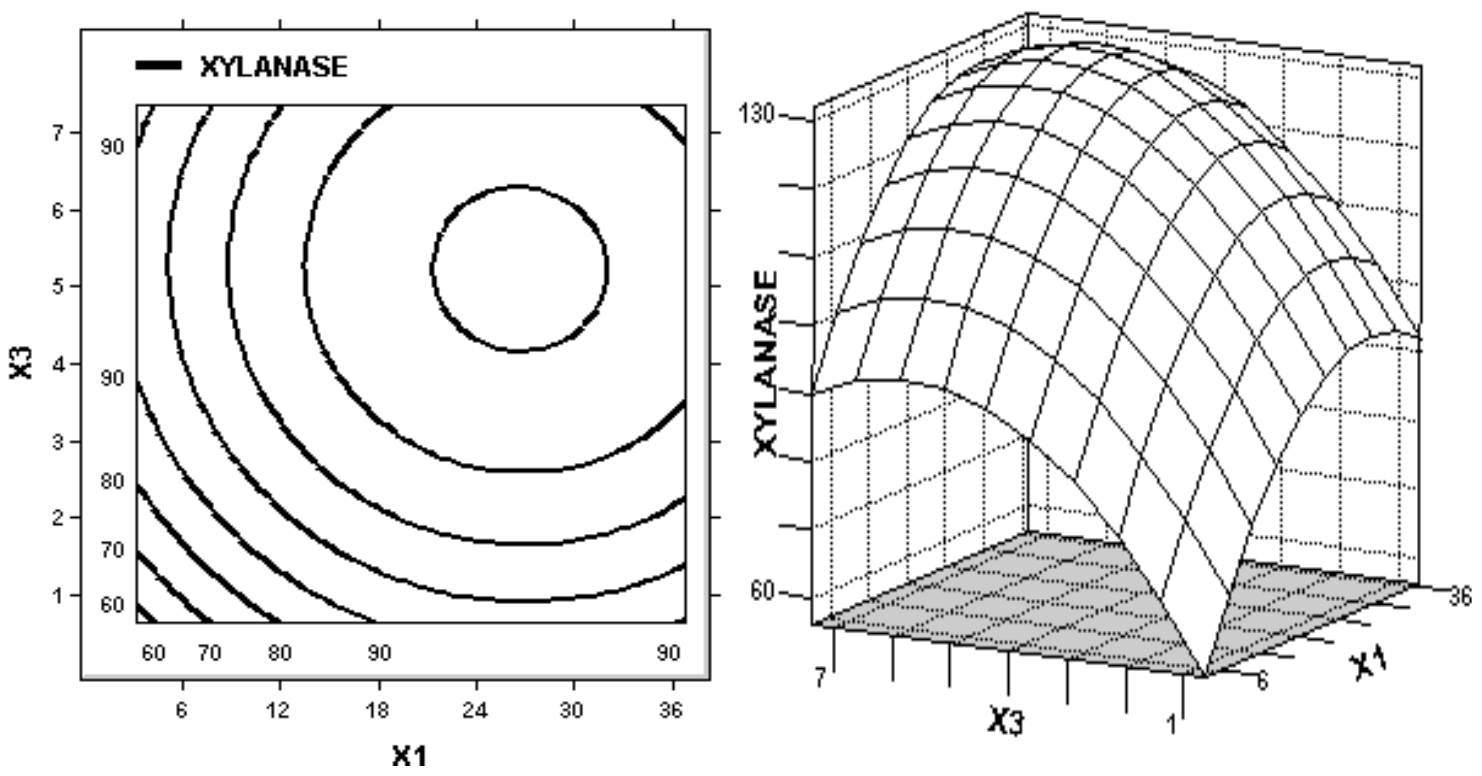

Figure 2B. Response surface plot and contour plot of the combined effects of Carbon and $\mathrm{KH}_{2} \mathrm{PO}_{4}$ on the xylanase production by $T$. viride HG 623 with constant cultivation time (120 h).
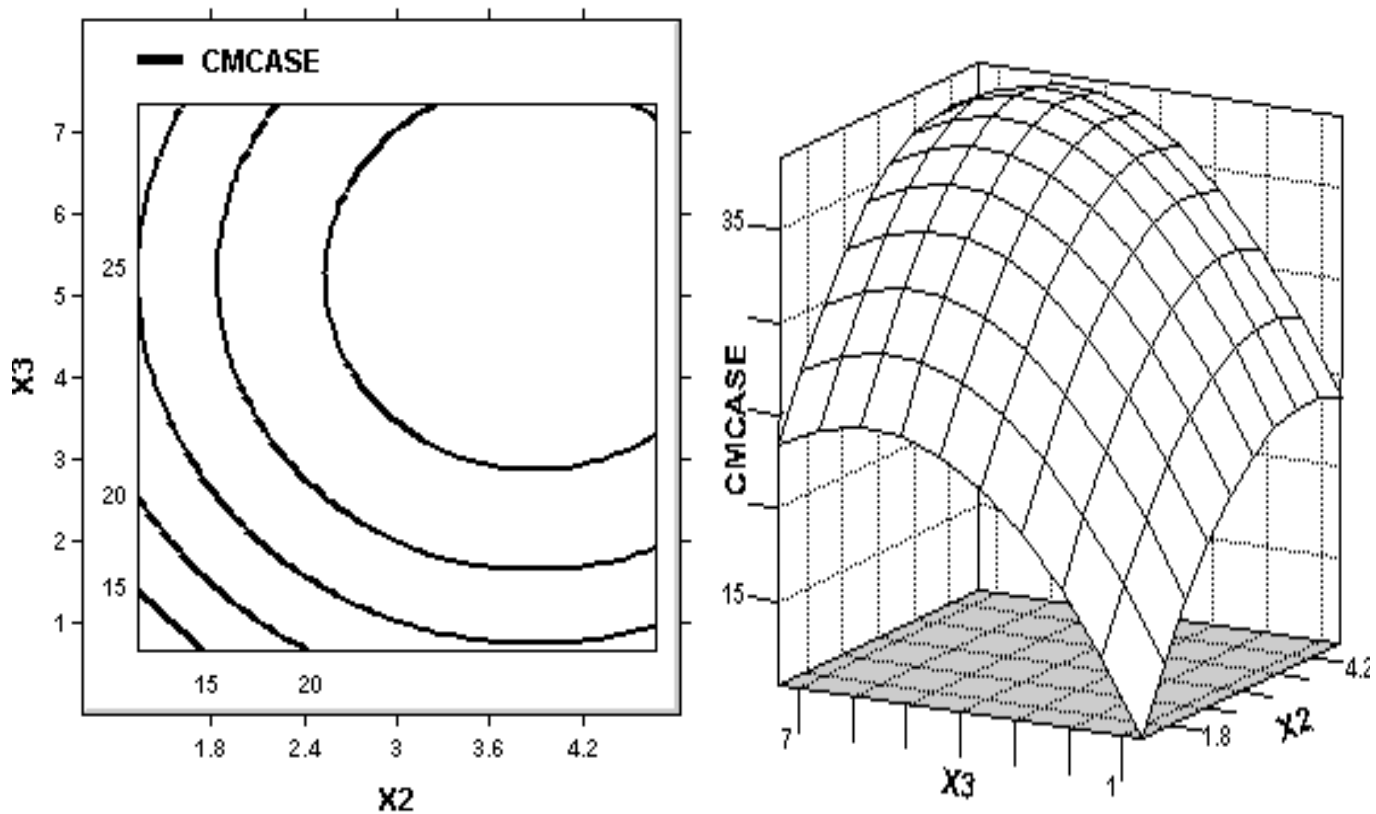

Figure 3A. Response surface plot and contour plot of the combined effects of $\mathrm{NH}_{4} \mathrm{Cl}$ and $\mathrm{KH}_{2} \mathrm{PO}_{4}$ on the CMCase production by T. viride HG 623 with constant cultivation time (120 h).

and endoglucanase activities were stable at $50^{\circ} \mathrm{C}$ when $\mathrm{pH}$ was between 3.0 to 7.5. The xylanase and endoglucanase activities were reduced dramatically beyond $\mathrm{pH}$ 8.0 (Figure 4D). The xylanase and endoglucanase from T. viride $\mathrm{HG} 623$ were stable over a wide $\mathrm{pH}$ range $(\mathrm{pH}$ 3.0-7.5) (Figure 4D) and the optimum enzyme activity of xylanase and endoglucanase was at 60 and $55^{\circ} \mathrm{C}$, respectively (Figure 4A).
To investigate the effect of metal ions on enzymatic activity, the crude enzyme was dissolved in the reaction buffer, which was added with a metal ion at a concentration of $75 \mathrm{mM}$. Several different buffer solutions were prepared, each spiked with a different metal. The variance analysis showed that xylanase $(\mathrm{F}=8.45, \mathrm{df}=11, \mathrm{P}<$ $0.05)$ and endoglucanase $(F=835.55, \mathrm{df}=11, \mathrm{P}<0.01)$ activities were significantly different in the presence of 

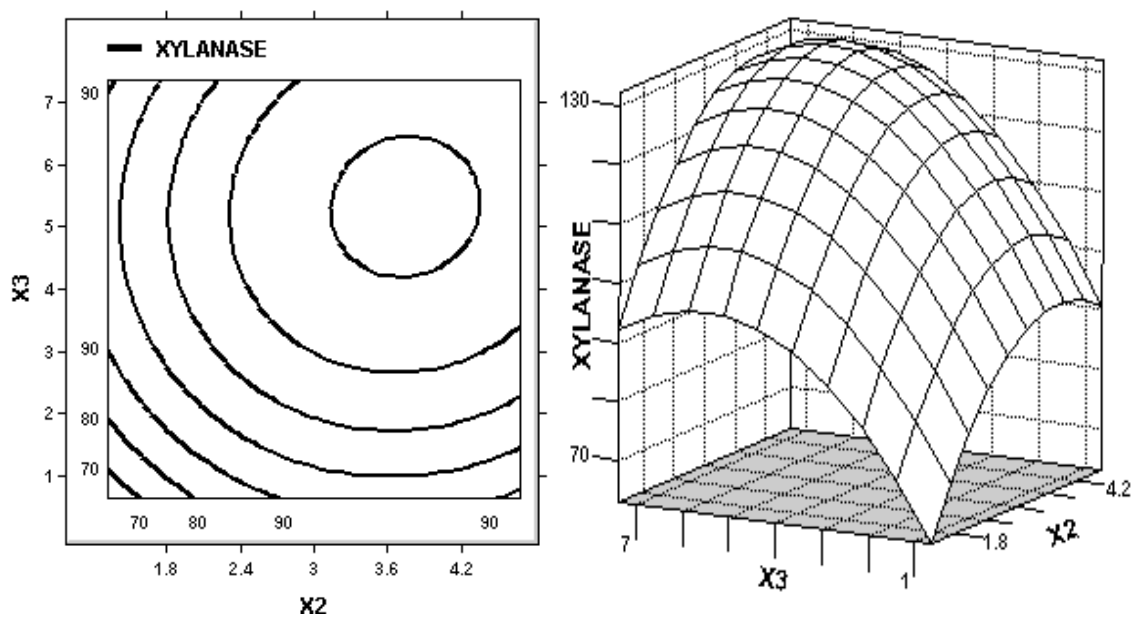

Figure 3B. Response surface plot and contour plot of the combined effects of $\mathrm{NH}_{4} \mathrm{Cl}$ and $\mathrm{KH}_{2} \mathrm{PO}_{4}$ on the xylanase production by $\mathrm{A} T$. viride $\mathrm{HG} 623$ with constant cultivation time $(120 \mathrm{~h})$.
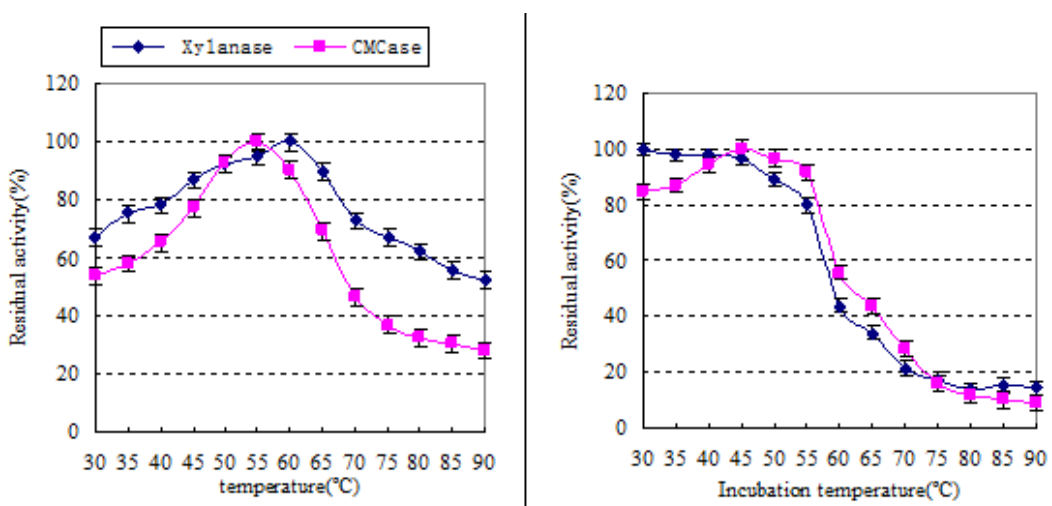

A

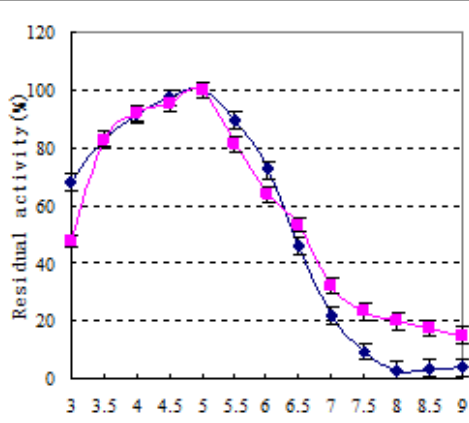

$\mathrm{DH}$

$\mathrm{C}$

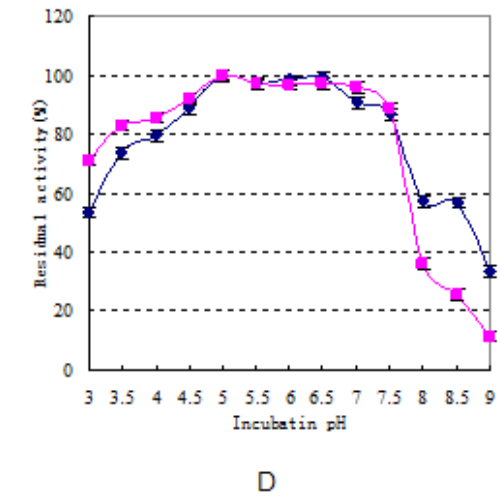

Figure 4. Activities and properties of endoglucanase and xylanase from $T$. viride $\mathrm{HG}$ 623. A. Effects of temperature on endoglucanase and xylanase activities of $T$. viride $\mathrm{HG} \mathrm{623.} \mathrm{The} \mathrm{enzyme} \mathrm{activity} \mathrm{was} \mathrm{measured} \mathrm{at} 30$ to $90^{\circ} \mathrm{C}$ for $30 \mathrm{~min}$ at $5^{\circ} \mathrm{C}$ intervals $(\mathrm{pH}$ 5.6). B. Effects of temperature on endoglucanase and xylanase stability of $T$. viride $\mathrm{HG}$ 623. The dialyzed fraction ( $\mathrm{pH} \mathrm{5.2)} \mathrm{was} \mathrm{incubated} \mathrm{at} 30$ to $90^{\circ} \mathrm{C}$ for $1 \mathrm{~h}$ at $5^{\circ} \mathrm{C}$ intervals, and then the residual activity was measured by incubation at $50^{\circ} \mathrm{C}$ for $30 \mathrm{~min}$. C. Effects of $\mathrm{pH}$ on endoglucanase and xylanase activities of $T$. viride HG 623. The enzyme activity was measured in the reaction buffer at different $\mathrm{pH}$ values between 3 and 9 at intervals of $0.5 \mathrm{pH}$ units. D. Effects of $\mathrm{pH}$ on endoglucanase and xylanase stability of $T$. viride $\mathrm{HG} 623$. The dialyzed fraction was incubated in different $\mathrm{pH}$ buffers $(\mathrm{pH} 3.0-9.0)$ at $4^{\circ} \mathrm{C}$ for $48 \mathrm{~h}$, and then the residual activity was measured under standard conditions $(\mathrm{pH}=5.0)$. All the experiments were performed three times. 


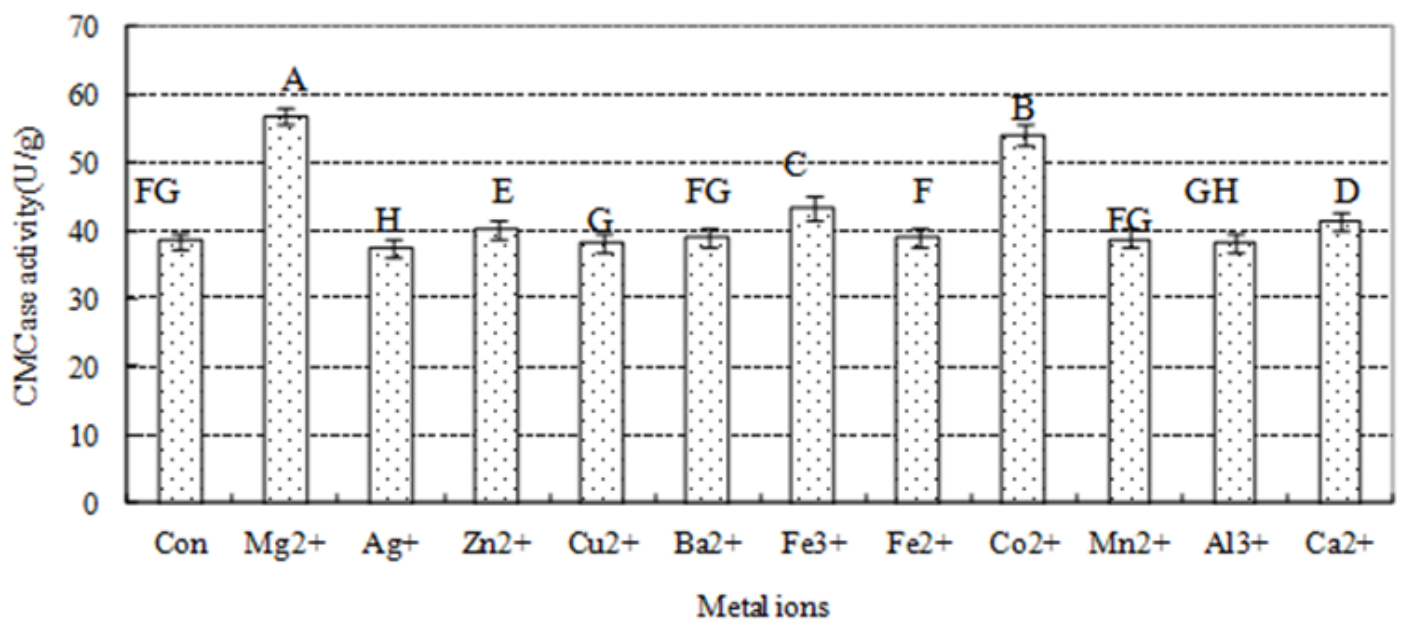

A

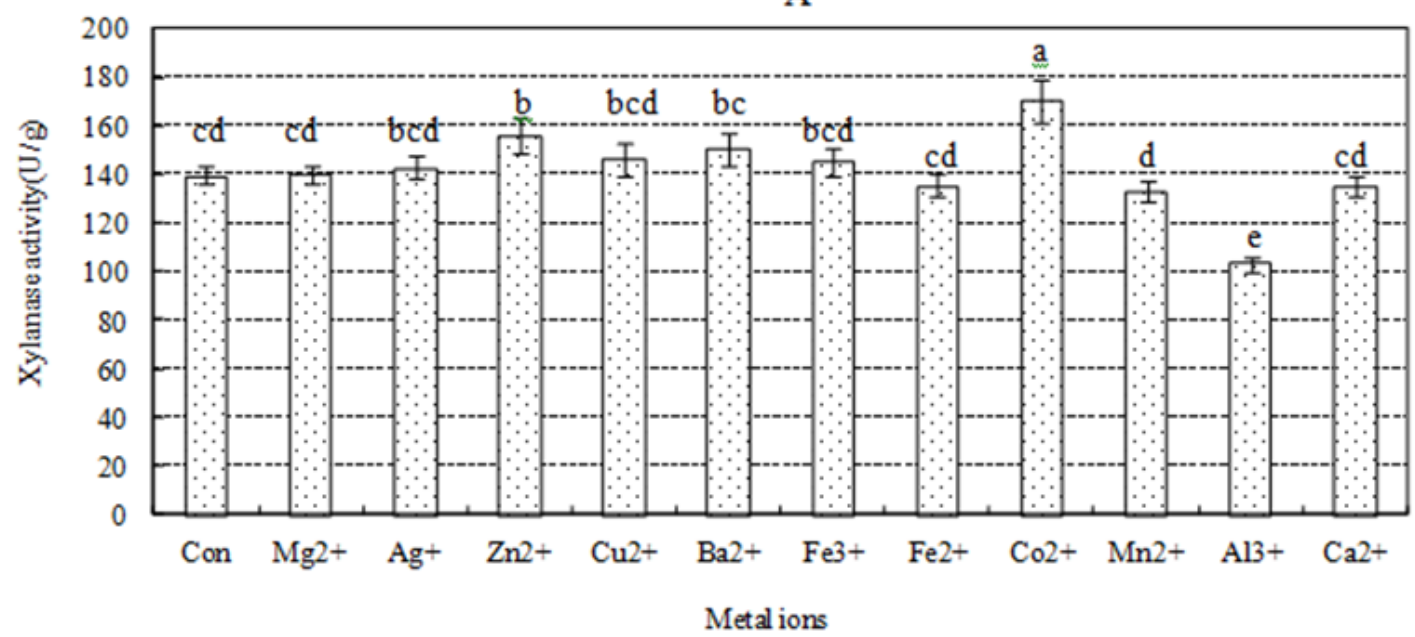

B

Figure 5. Effects of exposure to different metal ions on the endoglucanase and xylanase activities of $T$. viride HG 623. A. Effect of different metal ions on the endoglucanase activity. B. Effect of different metal ions on the xylanase activity. Several different reaction buffers were prepared, each spiked with $75 \mathrm{mM}$ of a metal ion. One unit of endoglucanase and xylanase activity were defined as the amount of enzyme required for releasing total reduced sugar equivalent to $1 \mathrm{mmol}$ glucose or xylose per minute, respectively. Con: control; the enzyme activity of $T$. viride HG 623 was measured under the normal reaction condition without any additional ions. The experiments were performed three times. Different letters above the columns indicate a significant difference determined by Duncan's multiple comparisons test $(A: P<0.01 ; B: P<0.05)$.

different metal ions. The activity of endoglucanase in $T$. viride $\mathrm{HG} 623$ was stimulated slightly by $\mathrm{Mg}^{2+}, \mathrm{Co}^{2+}, \mathrm{Fe}^{3+}$, $\mathrm{Ca}^{2+}$ and $\mathrm{Zn}^{2+}$, and strongly by $\mathrm{Mg}^{2+}$ and $\mathrm{Co}^{2+}$, but was inhibited by $\mathrm{Ag}^{+}$. When $\mathrm{Co}^{2+}$ was present, the activity of xylanase was stimulated strongly. However, xylanase activity was inhibited by $\mathrm{Al}^{3+}$ (Figure 5 ).

To investigate the effect of different substrates on enzymatic activity, the variance analysis showed that enzyme activity was significantly different $(F=166.36, \mathrm{df}=10, \mathrm{P}$ $<0.01$ ) in the presence of different substrates. CMC synthesized substrates, did not have significant differences with wheat bran (Figure 6). These results indi-cate that wheat bran was optimal substrate for enzyme production in natural substrate.

\section{DISCUSSION}

The nutritional component showed the significant effect on cellulase and hemicellulase production of microorganisms. The enzyme activities of cellulase and hemicellulase could be improved when cultured in mixed carbon resources. It has been reported that culture medium containing rice straw and wheat bran (1:3) as carbon source increased maximal cellulases and xylanases production by Scytalidium thermophilum (Jatinder et al., 2006). Sushil Nagar reported a cumulative effect of peptone, yeast extract, and $\mathrm{KNO}_{3}$ onxylanaseproductionby Bacilluspumilus SV-85S (Nagar et al., 2010). Phosphate concentrations had a potential influence on the fungus morphology and 


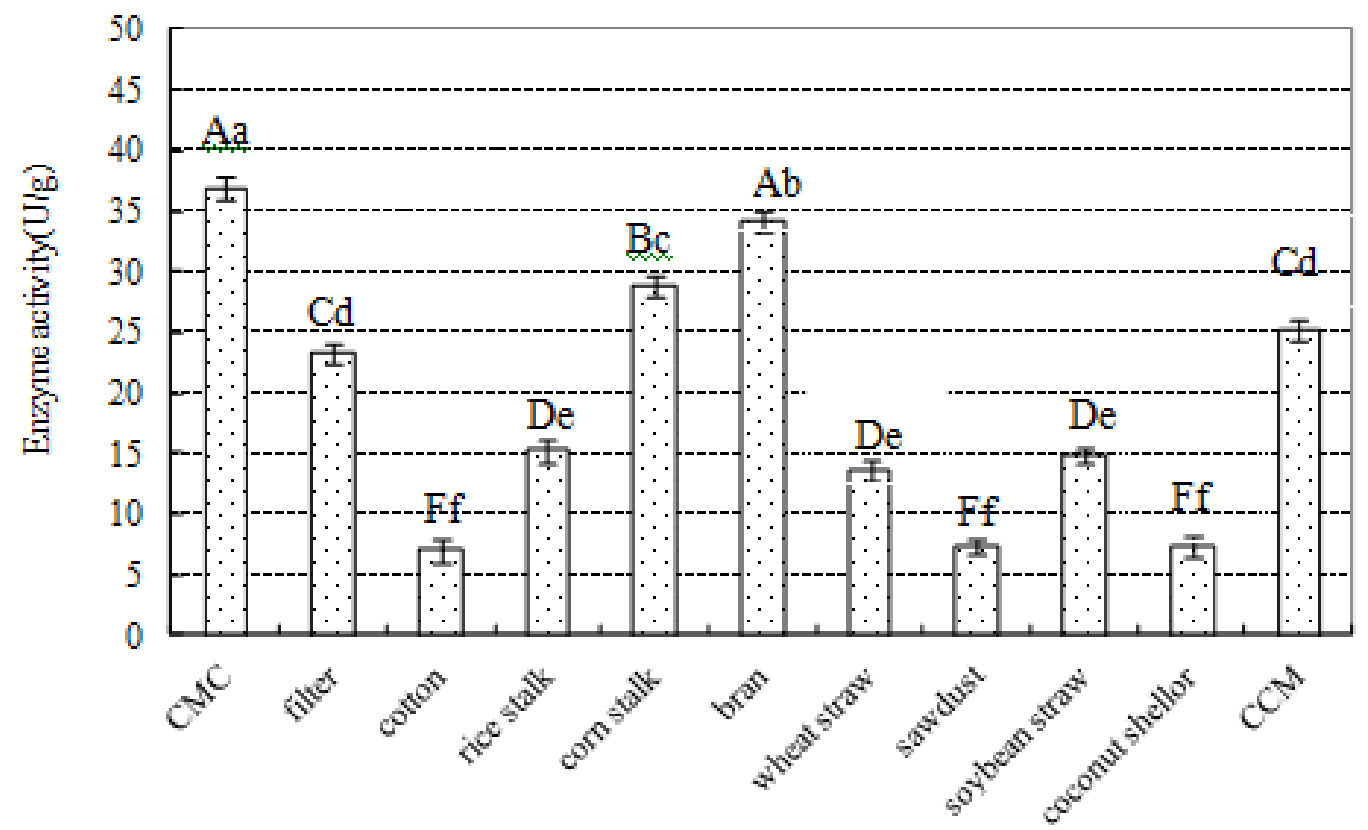

Figure 6. Effects of exposure to different substrates on the enzyme activity $T$. viride HG 623. Con: control, the activity of $T$. viride HG 623 was measured under the normal reaction condition with $\mathrm{CMC}-\mathrm{Na}$ as carbon sources. The experiments were performed three times. Different letters above the columns indicate a significant difference determined by Duncan's multiple comparisons test $(\mathrm{P}<0.01)$.

xylanase activity (Siedenberg et al., 1997). These indicated that various fungi had different ability of utilization of nutrients for enzyme production. In our research, mixed carbon resource, $\mathrm{NH}_{4} \mathrm{Cl}$ and $\mathrm{KH}_{2} \mathrm{PO}_{4}$ showed significant effects on enzymes production at the $5 \%$ level. The lower value of coefficient of variation (CV) shows the higher reliability of experiment (Box et al., 1978). In our study, the lower value of CV (4.05 and 7.0206) shows the better accuracy and reliability of the experiments (Table 6).

Different microorganisms have different enzyme characterization. The optimal temperature of xylanase and endoglucanase from $T$. viride $\mathrm{HG} 623$ were at $60^{\circ} \mathrm{C}$ and $55^{\circ} \mathrm{C}$, respectively, and they were stable over a wide $\mathrm{pH}$ range ( $\mathrm{pH}$ 3.0-7.5) (Figure 4A and 4D ). In comparison, the optimal temperature of xylanase from $T$. viride $\mathrm{HG}$ 623 was higher than that of the Bacillus sp JB99 $\left(45^{\circ} \mathrm{C}\right)$ (Kumar et al., 2011), and endoglucanase from $T$. viride HG 623 had a wider pH range than that of Mucor circinelloides ( $\mathrm{pH}$ 5.0-9.0) (Saha, 2004). The activity of endoglucanase in $T$. viride $H G 623$ was stimulated strongly by $\mathrm{Mg}^{2+}$ and $\mathrm{Co}^{2+}$, but was inhibited by $\mathrm{Ag}^{+}$. When $\mathrm{Co}^{2+}$ were present, the activity of xylanase was stimulated strongly. However, xylanase activity was inhibited by $\mathrm{Al}^{3+}$ (Figure 5). Quay et al. (2011) reported that endoglucanase from Aspergillus niger was inhibited by $\mathrm{Mn}^{2+}$, $\mathrm{Co}^{2+}, \mathrm{Zn}^{2+}, \mathrm{Mg}^{2+}, \mathrm{Ba}^{2+}, \mathrm{Fe}^{2+}, \mathrm{Ca}^{2+}$ and $\mathrm{K}^{+}$. The xylanase was strongly inhibited by $\mathrm{Hg}^{2+}$ in Aspergillus niveus RS2. These results show that enzyme from different species may be affected by different ions. Wheat bran was the optimal substrate for enzyme activity, which could maybe relate to the concentrations and structure of cellulose and hemicelluloses of the wheat bran.

In summary, a maximum endoglucanase activity was $40.89 \mathrm{IU} / \mathrm{g}$ following final optimal condition [Carbon (26.99 g/L), $\mathrm{NH}_{4} \mathrm{Cl}(3.80 \mathrm{~g} / \mathrm{L})$, and $\mathrm{KH}_{2} \mathrm{PO} 4$ (5.23 g/L)] and a maximum xylanase activity was $135.51 \mathrm{lU} / \mathrm{g}$ following final optimal condition [Carbon $(26.91 \mathrm{~g} / \mathrm{L}), \mathrm{NH}_{4} \mathrm{Cl}$ $(3.77 \mathrm{~g} / \mathrm{L})$, and $\left.\mathrm{KH}_{2} \mathrm{PO} 4(5.31 \mathrm{~g} / \mathrm{L})\right]$. The xylanase and endoglucanase activity of $T$. viride $H G 623$ showed the highest at 60 and $55^{\circ} \mathrm{C}$ at $\mathrm{pH} 5.6$. The activity of xylanase was stimulated strongly by $75 \mathrm{mM}$ of $\mathrm{Co}^{2+}$, and the activity of endoglucanase was stimulated strongly by $75 \mathrm{mM}$ of $\mathrm{Mg}^{2+}$ and $\mathrm{Co}^{2+}$.

The xylanase and endoglucanase enzymatic activity of $T$. viride $\mathrm{HG} 623$ were stable at $\mathrm{pH} 3.0$ to 7.5 at $50^{\circ} \mathrm{C}$ or when incubated from 35 to $55^{\circ} \mathrm{C}$ for $1 \mathrm{~h}$. Wheat bran was the optimal substrate for enzyme activity in natural substrate.

\section{ACKNOWLEDGEMENTS}

This research was funded by the Science and Technology Program in Educational Department of Heilongjiang Province (12511062), Postdoctoral Science Starting Funds Program of Heilongjiang Province (LBH-Q09169), Doctoral Starting Funds Program of Northeast Agricultural University (2010RCB24) and National Natural Science Foundation (31272484). 


\section{REFERENCES}

Agbogbo FK, Coward KG (2008). Cellulosic ethanol production using the naturally occurring xylose-fermenting yeast, Pichia stipitis. Biotechnol. Lett. 30: 1515-1524.

Box GEP, Wilson KB (1951). On the experimental attainment of optimum conditions. J. Roy. Stat. 13: 1-45.

Box GEP, Hunter WG, Hunter WG, Hunter JS (1978). Statistics for experimenters. Jhon Wiley and Sons, America. pp. 291-334.

Cardona CA, Sánchez OJ (2007). Fuel ethanol production: process design trends and integration opportunities. Bioresour. Technol. 98: 2415-2457.

Evangelos T, Petros K, Dimitris K, Basil JM, Paul C (2003). Production and partial characterization of xylanase by Sporotrichum thermophile under solid-state fermentation. World J. Microbiol. Biotechnol. 19: 195-198.

García-Aparicio MP, Ballesteros M, Manzanares P, Ballesteros I, González A , Negro MJ (2007). Xylanase contribution to the efficiency of cellulose enzymatic hydrolysis of barley straw. Appl. Biochem. Biotechnol. 137-140(1-12): 353-365.

Geetha K, Gunasekaran P (2010). Optimization of nutrient medium containing agricultural waste for xylanase production by Bacillus pumilus B20. Biotechnol. Biopro. Eng. 15: 882-889.

Irfan M, Nadeem M, Syed Q (2012). Influence of Nutritional Conditions for Endoglucanase Production by Trichoderma viride in SSF. Global. J. Biotechnol. Biochemis. 7: 7-12.

Jahromi MF, Liang JB, Rosfarizan M, Goh YM, Shokryazdan P (2011). Efficiency of rice straw lignocelluloses degradability by Aspergillus terreus ATCC 74135 in solid state Fermentation. Afr. J. Biotechnol. 10: 4428-4435.

Jatinder K, Chadha BS, Saini HS (2006). Optimization of culture conditions for production of cellulases and xylanases by Scytalidium thermophilum using response surface methodology. World J. Microbiol. Biotechnol. 22: 169-176.

Kumar SS, Panday DD, Naik GR (2011). Purification and molecular characterization of low molecular weight cellulase-free xylanase from thermoalkalophilic bacillus spp. jb 99. World J. Sci. Technol. 1: 09-16.

Li Y, Liu Z, Cui F, Xu Y, Zhao H (2007a). Application of statistical experimental design to optimize culture requirements of a novel Aspergillus sp. $\mathrm{ZH}-26$ producing endoxylanase from agricultural waste material and evaluation of its performance on the degradation of arabinoxylans in mashing. J. Food Sci. 72: 320-329.

Maria LGS, Samia MTT, Daniel MTT (2009). Screening of culture condition for xylanase production by filamentous fungi. Afr. J. Biotechnol. 8: 6317-6326.

Meinke A, Damude HG, Tomme P, Kwan E, Kilburn DG, Miller RCJ, Warren RA, Gilkes NR (1995). Enhancement of the Endo- $\beta-1,4-$ glucanase Activity of an Exocellobiohydrolase by Deletion of a Surface Loop. J. Biol. Chem. 270: 4383-4386.

Miller GL (1959). Use of dinitrosalicylic acid reagent for determination of reducing sugars. Anal. Chem. 31: 426-428.

Nagar S, Gupta VK, Kumar D, Kumar L, Kuhad CR (2010). Enhancing Jatropha oil extraction yield from the kernels assisted by a xylandegrading bacterium to preserve protein structure. J. Ind. Microbiol. Biotechnol. 37: 71-83.
Plackett RL, Burman JP (1946). The design of optimum multifactorial experiments. Biometrik. 37: 305-325.

Quay DHX, Bakar FDA, Rabu A, Said M, Illias RM, Mahadi NM, Hassan $O$, Murad AMA (2011). Overexpression, purification and characterization of the Aspergillus niger endoglucanase, EglA, in Pichia pastoris. Afr. J. Biotechnol. 10: 2101-2111.

Quiroz CRE, Pérez MN, Martínez AC, Acosta U, Folch MJ (2011). Evaluation of different lignocellulosic substrates for the production of cellulases and xylanases by the basidiomycete fungi Bjerkandera adusta and Pycnoporus sanguineus. Biodegradation 22: 565-572.

Romdhane IBB, Achouri IM, Hafedh B (2010). Improvement of Highly Thermostable Xylanases Production by Talaromyces thermophilus for the Agro-industrials Residue Hydrolysis. Appl. Biochemis. Biotechnol. 162: 1635-1646.

Saha BC (2004). Production, purification and properties of endoglucanase from a newly isolated strain of Mucor circinelloides. Process. Biochem. 39: 1871-1876.

Shin JH, Choi JH, Lee OS, Kim YM, Lee DS, Kwak YY, Kim WC, Rhee IK (2009). Thermostable xylanase from Streptomyces thermocyaneoviolaceus for optimal production of xylooligosaccharides. Biotechnol. Biopro. Eng. 14: 391-399.

Siedenberg D, Gerlach SR, Czwalinna A, Schugerl K, Giuseppin MLF, Hunik J (1997). Production of xylanase by Aspergillus awamori on complex medium in stirred tank and airlift tower loop reactors. J. Biotechnol. 56: 205-216.

Silva CJSM, Roberto IC (2001). Optimization of xylitol production by Candida guilliermondi FTI 20037 using response surface methodology. Process Biochem. 36: 1119-1124.

Sonia KG, Chadha BS, Saini HS (2005). Sorghum straw for xylanase hyper-production by Thermomyces lanuginosus (D2W3) under solidstate fermentation. Bioresour. Technol. 96: 1561-1569.

Van WJPH, Mohulatsi M (2003). Biodegradation of wastepaper by cellulase from Trichoderma viride. Bioresour. Technol. 86: 21-23.

Yoon JJ, Cha CJ, Kim YS, Kim W (2008). Degradation of cellulose by the major endoglucanase produced from the brown-rot fungus Fomitopsis pinicola. Biotechnol. Lett. 30: 1373-1378.

Zhang JH, Siika-aho M, Puranen T, Tang M, Tenkanen M, Viikari L (2011). Thermostable recombinant xylanases from Nonomuraea flexuosa and Thermoascus aurantiacus show distinct properties in the hydrolysis of xylans and pretreated wheat straw. Biotechnol. Biofuel 4: 12 . 